\section{Anal human papillomavirus infection in heterosexuals with genital warts: prevalence and relation with sexual behaviour}

\author{
C Sonnex, J H Scholefield, G Kocjan, G Kelly, \\ C Whatrup, A Mindel, J M A Northover
}

Academic Department of
Genitourinary Medicine and Department of

Histopathology, University

College and Middlesex

Hospital School of

Medicine, London W1

C Sonnex, MRCP, lecturer

$\mathrm{G}$ Kocjan, MRCPATH, senior

lecturer

G Kelly, PHD, statistician

A Mindel, MRCP, senior

lecturer

Imperial Cancer Research

Fund Colorectal Cancer

Unit, St Mark's Hospital,

London EC1

J H Scholefield, FRCS,

research fellow

$C$ Whatrup, research nurse

J M A Northover, FRCS,

director

Correspondence to:

Dr C Sonnex, Department of

Genitourinary Medicine,

Addenbrooke's Hospital,

Cambridge CB2 2QQ.

BMF 1991;303:1243 to explain anal infection in heterosexual men. behaviours.

\section{Subjects, methods, and results}

The clinical and subclinical manifestations of anat human papillomavirus infection have been well reported in homosexual men.' Although anal warts have been reported to accompany genital warts in heterosexual men and women, ${ }^{23}$ the prevalence of subclinical anal human papillomavirus infection in heterosexual people has not been addressed previously. The mode of transmission of human papillomavirus to the anus is poorly understood and, although in some cases it may result from anal coitus, ${ }^{4}$ this fails

The aims of this study were to assess the prevalence of anal human papillomavirus infection in heterosexual men and women with genital warts and to examine whether anal infection is related to specific sexual

We recruited heterosexual men and women attending the department of genitourinary medicine with newly diagnosed anogenital warts or warts untreated in the previous three months. Demographic data and information on particular sexual practices such as anal coitus and receptive anodigital insertion during sexual foreplay or intercourse were obtained by direct questioning. Anal cytology was performed as described previously. 5 The perianal area and anal canal were examined with a colposcope before and after application of acetic acid. Colposcopic findings were categorised as $(a)$ normal; $(b)$ condylomata acuminata present; and $(c)$ acetowhite epithelium alone (suggesting subclinical human papillomavirus infection)-no condylomata visible. Cellular material was obtained by gently brushing the anus and anal canal with a Cytobrush and was subsequently analysed for the presence of human papillomavirus DNA by dot-blot hybridisation.

The study group comprised 95 women with vulval warts (without perineal involvement) and 42 heterosexual men (mean age 26 years) with penile warts. A further seven women and 13 men with anal warts without genital lesions were included in the analysis of sexual practices and anal infection. The table summarises the findings. Thirteen $(31 \%)$ of the men with penile warts had clinically obvious anal warts, six of whom $(46 \%)$ were unaware they had anal lesions. Forty five $(47 \%)$ of the women with vulval warts had anal warts, $24(53 \%)$ of whom were unaware of their presence. Colposcopically visible acetowhite lesions consistent with subclinical anal infection were recorded in the absence of anal warts in $18(43 \%)$ men and $30(32 \%)$ women. Fewer patients with normal findings on anal examination were found to have human papillomavirus infection by either cytological examination or DNA hybridisation.

A history of anoreceptive intercourse was obtained from $33 \%(9 / 27)$ of women with warts of the anal canal, none of 25 women with perianal warts alone, and 30\% $(6 / 20)$ of women with normal findings on anal examination, and a history of receptive anodigital insertion was given by $52 \%(14 / 27), 20 \%(5 / 25)$, and $40 \%(8 / 20)$ of the same groups respectively. A history of receptive anodigital insertion was obtained from $40 \%(8 / 20)$ of heterosexual men with warts of the anal canal, $20 \%$ (1/6) with perianal warts alone, and $43 \%(6 / 14)$ with normal findings on anal examination. Anal sexual practices were not significantly different between patients with anal warts and those with colposcopically normal findings on anal examination. Women with a history of receptive anodigital insertion, however, were more likely to have warts of the anal canal than perianal warts alone ( $p=0 \cdot 017$, Fisher's exact test).

Anal human papillomavirus infection in women with vulval warts and heterosexual men with penile warts. Figures are numbers (percentages)

\begin{tabular}{lcc}
\hline Evidence of anal infection & $\begin{array}{c}\text { Heterosexual } \\
\text { men }\end{array}$ & Women \\
\hline $\begin{array}{l}\text { Anal warts } \\
\begin{array}{c}\text { Occult } \\
\text { Anal acetowhite lesions (no warts } \\
\text { visible) }\end{array}\end{array}$ & $\begin{array}{c}13(31) \\
6(14) \dagger\end{array}$ & $\begin{array}{c}45(45) \\
24(25) \dagger\end{array}$ \\
$\begin{array}{l}\text { Clinically normal and positive for } \\
\text { human papillomavirus DNA: }\end{array}$ & $18(43)$ & $30(32)$ \\
$\begin{array}{l}\text { Positive on cytological examination } \\
\text { Negative on cytological examination }\end{array}$ & $1(2)$ & $7(7)$ \\
$\begin{array}{l}\text { Clinically normal and negative for } \\
\text { human papillomavirus DNA: } \\
\text { Positive on cytological examination } \\
\text { Negative on cytological examination }\end{array}$ & 0 & 0 \\
\hline Total & $5(12)$ & $4(4)$ \\
\hline
\end{tabular}

*Patient unaware of their presence.

tAs percentage of total number.

\section{Comment}

Clinical descriptions of anal warts date back to the first century AD. They were considered to be a sign of anal intercourse, an assumption that has persisted. Although anal warts may be associated with anal coitus, this fails to explain all cases. We found no association between the presence of anal warts and a history of anal sex in women nor with a history of receptive anodigital insertion by a sexual partner in heterosexual men and women. The high prevalence of anal human papillomavirus infection in this study emphasises the importance of examining the anus and anal canal of all patients presenting with genital warts. However, as the natural course of subclinical anal human papillomavirus infection is unknown and the specificity of anal acetowhitening and anal cytology are the subject of continuing research, ${ }^{5}$ the need to search routinely for subclinical infection by these methods in patients with genital warts must await further study.

1 Frazer IH, Medley G, Crapper RM, Brown TC, Mackay IR. Association between anorectal dysplasia, human papillomavirus and human immunodeficiency virus in homosexual men. Lancet 1986;ii:657-60.

2 Goorney BP, Waugh MA, Clarke J. Anal warts in heterosexual men. Genitourin Med 1987;63:216.

3 Oriel JD. Natural history of genital warts. Brf Vener Dis 1971:47:1-13.

4 Oriel JD. Anal warts and anal cius. Br 7 Vener Dis 1971:47:273-6.

5 Sonnex C Scholefield JH, Kocjan G. Kelly G. Whatrup C Mindel A, al Anal human papillomavirus infection: a comparative study of cytology, colposcopy, and DNA hybridisation as methods of detection. Genitourin Med scopy, and DNA
$1991 ; 67: 21-5$.

(Accepted I2 fuly 1991)

\section{Correction}

Prevention of deep vein thrombosis after hip replacement: randomised comparison between unfractionated heparin and low molecular weight heparin

An editorial error occurred in this paper by P F Leyvraz and others (7 September, $p$ 543). In the patients and methods section the second sentence under the heading "Prophylactic regimens" should read: "The first dose of 4000 IU [not 4.0 IU] was given about 16 hours before surgery." 